\title{
Physiotherapy services in the face of a pandemic
}

1. Escola Superior de Saúde Jean Piaget do Algarve - Instituto Piaget - Enxerim - 8300-025 - Silves - Portugal Research in Education and Community Intervention (RECI)

http://dx.doi.org/10.1590/1806-9282.66.4.491

\section{SUMMARY}

BACKGROUND: Physiotherapy services are necessary for hospitalized patients of COVID-19 as well as chronic patients. Thus, physiotherapists present an increased risk of exposure to coronavirus. This study aimed to determine the number of physiotherapists who interrupted their services because of the COVID-19 pandemic and to verify the procedures adopted by the ones who are still working.

METHODS: The sample comprised 619 physiotherapists who worked in Portugal, 154 (24.9\%) male and 465 (75.1\%) female, aged between 22 and 67 years (34.47 8.70). The measurement instrument was an on-line questionnaire applied in late March 2020 through contacts and social networks.

RESULTS: 453 (73.2\%) physiotherapists interrupted their work activities in person because of the pandemic and 166 (26.8\%) continue to work in person. The main measures adopted by physical therapists who continue to work in person included: hand washing (21.5\%), mask use (20.3\%), material disinfection (19.3\%) and, glove use (19.3\%). Of the physiotherapists who are not working in person ( $n=453)$, 267 (58.9\%) continue to monitor their patients at a distance, and 186 (41.1\%) are not monitoring the patients. The main measures used by physiotherapists to monitor their patients at a distance included: written treatment prescription (38\%), making explanatory videos (26.7\%), and synchronous video conference treatment (23.5\%).

CONCLUSIONS: Our data revealed that most of the physiotherapists interrupted their face-to-face practices because of the COVID-19 pandemic, however, once they do not follow up their patients' treatment in person, most of them adapted to monitor their patients from a distance.

KEYWORDS: COVID-19, physical therapists, adopted measures, pandemic, health professionals

\section{INTRODUCTION}

Coronaviruses are a group of viruses belonging to the family of Coronaviridae, enveloped, positive single-stranded large RNA viruses with "human-to-human" transmission through respiratory secretions. ${ }^{1,2}$
The first case of coronavirus disease 2019 (COVID19) was reported in Wuhan, Hubei Province of China, on 31 December 2019, ${ }^{1,3}$ and the cumulative COVID19 case number increased quickly. Currently (April 6,

DATE OF SUBMISSION: 07-Abr-2020

DATE OF ACCEPTANCE: 08-Abr-2020

CORRESPONDING AUTHOR: Beatriz Minghelli

E-mail: beatriz.minghelli@silves.ipiaget.pt 
2020), COVID-19 was classified, by the World Health Organization (WHO), as a pandemic detected in 203 countries, with 348867 positive cases and which caused 16,351 deaths. $^{3}$

The clinical manifestations of COVID-19 comprise fever, cough, nasal congestion, fatigue, and other signs of upper respiratory tract infections including dyspnoea and severe chest symptoms corresponding to pneumonia, ${ }^{1,4-6}$ and, to date, no specific therapeutic drug has been found.

WHO recommendations include frequent hand washing, social isolation, avoid touching the eyes, nose, and mouth, practice respiratory hygiene (to cover the nose and mouth with a flexed elbow or disposable tissue when coughing and sneezing), in case of fever, cough and difficulty breathing, seek medical attention early. ${ }^{5,7}$

Health care professionals are at the front line of providing care to patients with COVID-19, so they have an increased risk of occupational exposure to coronavirus. In this way, health professionals have to comply with a series of prevention and infection control recommendations to minimize the risk of infection. ${ }^{5}$

In Portugal, as well as in other countries, the number of cases of COVID-19 has increased every day, with 2 positive cases being detected on March 2 and, today (April 6, 2020), the number of infected people is 11,730 with 311 dead. The Portuguese Directorate-General for Health decided on several measures to be followed by health professionals, including hand hygiene, the use of a surgical mask (or the appropriate PPE for clinical activity), daily self-monitoring to identify early suggestive symptoms of COVID-19. ${ }^{8}$

Physiotherapy is the 3rd largest profession in the area of healthcare and is the most representative profession in the area of Rehabilitation in Portugal. Physiotherapy services provide the development, maintenance, and recovery of people's movement and functional ability, improving their quality of life. ${ }^{9}$ In this way, many hospitalized patients in the acute phase of COVID-19, as well as chronic patients, need physical therapy services. The World Confederation for Physical Therapy (WCPT) has prepared a document that describes the recommendations for physical therapy management for COVID-19 in a hospital setting for acute cases. ${ }^{10}$

The purpose of this study was to determine the number of physiotherapists who interrupted their services because of the COVID-19 pandemic and to verify the procedures adopted by the physiotherapists who are still working.

\section{METHODS}

This is a cross-sectional study developed to obtain data about the employment situation of physiotherapists working in Portugal.

This research has been approved by the Research in Education and Community Intervention (RECI) research center. All participants were informed of the objectives of the study and that the anonymity of the responses would be ensured, having given their consent to participate in this study.

\section{Population}

This studied population consisted of physiotherapists of all sexes and ages.

The research inclusion criteria defined physiotherapists who worked in Portugal, who were working in clinical practice, and who freely agreed to participate in this research.

According to data from the Portuguese Association of Physiotherapists, the number of physiotherapists in Portugal is 13,000 (population). The sample size was determined using an estimated mean injury prevalence of $50 \%$, and assuming an error margin of $5 \%$ with a 95\% confidence interval (CI). Using these assumptions, the minimum sample size contained 374 physiotherapists. ${ }^{11}$

\section{Measurement instrument}

The measurement instrument was an on-line questionnaire. Data collection took place between 26 and 30 March 2020. The questionnaires were disseminated through telephone contacts via WhatsApp, emails, social networks, and on institutional pages.

Since questionnaires on this topic are unknown, this measurement instrument was developed by the authors and, subsequently, had its content validity subjected to critical analysis (by Ph.D. Physiotherapist Professors) based on an objective approach to the analysis of statements used to measure a concept. Then, this questionnaire was submitted to a pre-test, having been sent to 3 physical therapists.

This questionnaire included questions about gender, age, years of professional practice, the region of practice, the subgroup of physiotherapy usually practiced on (could pick more than one), self-employed or employed, if they kept a person-to-person clinical practice and, if so, which prevention measures are being taken. The physiotherapists that were not working on a person-to-person clinical practice should say why, whether they started monitoring their patients 
from distance and, if so, indicate how, if the number of sessions per week was being kept, and if the amount charged was the same.

\section{DATA ANALYSIS}

Statistical analysis was performed with Statistical Package for Social Sciences (SPSS), version 26.0, and descriptive statistics were performed. Chi-square was used to test for a significant association between categorical variables. Statistical significance was set at 0.05 .

\section{RESULTS}

Of the 630 questionnaires delivered, 2 were excluded because they had errors in filling out and 9 were excluded because the physiotherapists were not working in Portugal. Thus, the sample consisted of 619 physiotherapists, with 154 (24.9\%) males and 465 (75.1\%) females, aged between 22 and 67 years (34.47 \pm 8.70 years old). The sample was $65 \%$ higher than expected for the population's representativeness.

Years of practice in the profession ranged from 4 months to 43 years $(11.42 \pm 8.69$ years).

Regarding the area of intervention, the physiotherapist was given the option to choose more than one area, with the majority working in the musculoskeletal area (28\%), followed by trauma-orthopedics (15.9\%), 13.7\% neurology, $12.9 \%$ geriatrics, continuous and palliative care, $10.6 \%$ general practice, $9.1 \%$ cardiorespiratory, $8.4 \%$ pediatrics, $0.7 \%$ urogynecology, $0.4 \%$ dermatofunctional, and $0.3 \%$ in other areas of intervention.

A total of 390 (63\%) physiotherapists were employed and 229 (37\%) were self-employed.

Currently, 453 (73.2\%) physiotherapists interrupted their work activities in person due to the pandemic, and $166(26.8 \%)$ continue to work in person.

Of the physical therapists who continue to work in person, 27 (16.3\%) were self-employed and 139 (83.7\%) were employed. Of the physical therapists who interrupted their physical activities, 202 (44.6\%) were self-employed and 251 (55.4\%) were employed $(\mathrm{p} \leq 0.001)$.

Table 1 shows the association between the interruption of the profession and the area of Portugal in which the physical therapist practices.

The measures adopted by physiotherapists who are still working are shown in figure 1.
Of the physiotherapists who are not working in person ( $\mathrm{n}=453)$, 49\% (257 responses) answered that they stopped their work activity at their own will and 51\% (268 responses) due to the imposition of the workplace.

Still considering physiotherapists who are not working in person, $267(58.9 \%)$ continue to monitor their patients at a distance, and $186(41.1 \%)$ are not monitoring patients. Figure 2 shows the measures used by physiotherapists to monitor their patients from a distance.

Of the physiotherapists who continue to monitor their patients remotely $(\mathrm{n}=267), 36(13.5 \%)$ maintained the frequency of their weekly sessions, and 231 (86.5\%) changed the frequency of treatment. Only 22 (8.2\%) physiotherapists maintained the same amount charged per remote treatment session and the majority $(245 ; 91.8 \%)$ changed the price for this new type of distance treatment.

\section{DISCUSSION}

Data of this study revealed that most physiotherapists interrupted their in-person practices because of the COVID-19 pandemic, and many of them (47\%) were self-employed, which means they had to adjust their financial situation due to this interruption.

To minimize the impact of this public health crisis due to the new coronavirus, the Portuguese government has extended the deadline of State contribution payments for self-employed workers, exceptional financial support has also been created for workers who have to stay at home; for those staying home

TABLE 1.PRACTICE OF THE PROFESSION IN PERSON DISTRIBUTED OVER THE AREAS OF PORTUGAL

\begin{tabular}{l|l|l|l}
\multirow{2}{*}{ Portugal areas } & \multicolumn{2}{|l|}{$\begin{array}{l}\text { Practice of the profession in } \\
\text { person }\end{array}$} & Total \\
\cline { 2 - 3 } & $\begin{array}{l}\text { Still prac- } \\
\text { ticing }\end{array}$ & $\begin{array}{l}\text { Interruption } \\
\text { of practice }\end{array}$ & \\
\hline Azores archipelago & 0 & $9(2 \%)$ & $9(1.5 \%)$ \\
\hline $\begin{array}{l}\text { Autonomous Re- } \\
\text { gion of Madeira }\end{array}$ & $3(1.8 \%)$ & $8(1.8 \%)$ & $11(1.8 \%)$ \\
\hline North region & $37(22.3 \%)$ & $134(29.6 \%)$ & $171(27.6 \%)$ \\
\hline Center region & $20(12 \%)$ & $64(14.1 \%)$ & $84(13.6 \%)$ \\
\hline $\begin{array}{l}\text { Lisbon and Vale do } \\
\text { Tejo }\end{array}$ & $61(36.7 \%)$ & $154(34 \%)$ & $215(34.7 \%)$ \\
\hline Alentejo & $7(4.2 \%)$ & $18(4 \%)$ & $25(4 \%)$ \\
\hline $\begin{array}{l}\text { Algarve (South } \\
\text { region) }\end{array}$ & $37(22.3 \%)$ & $62(13.7 \%)$ & $99(16 \%)$ \\
\hline Did not mention & $1(0.6 \%)$ & $4(0.9 \%)$ & $5(0.8 \%)$ \\
\hline Total & 166 & 453 & $619(100 \%)$ \\
\hline
\end{tabular}




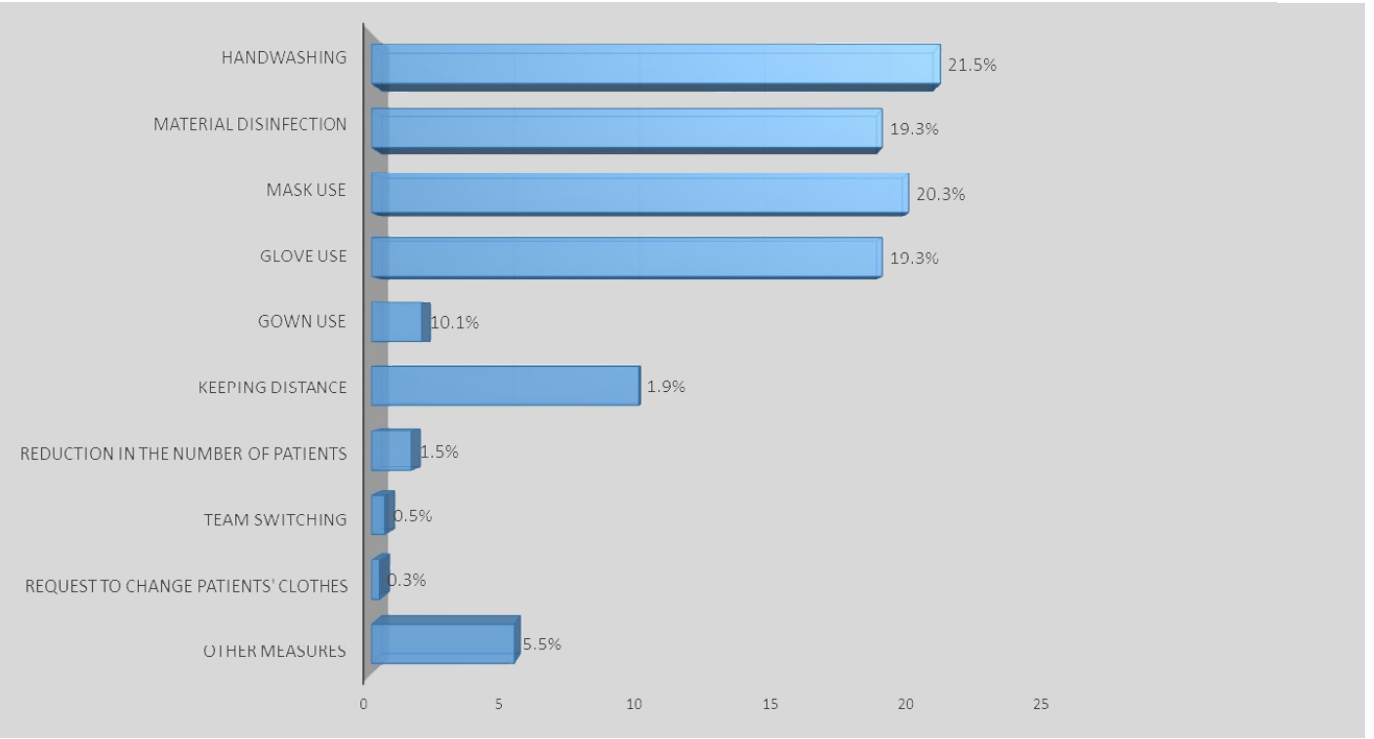

FIGURE 1. PREVENTIVE MEASURES ADOPTED BY PHYSIOTHERAPISTS

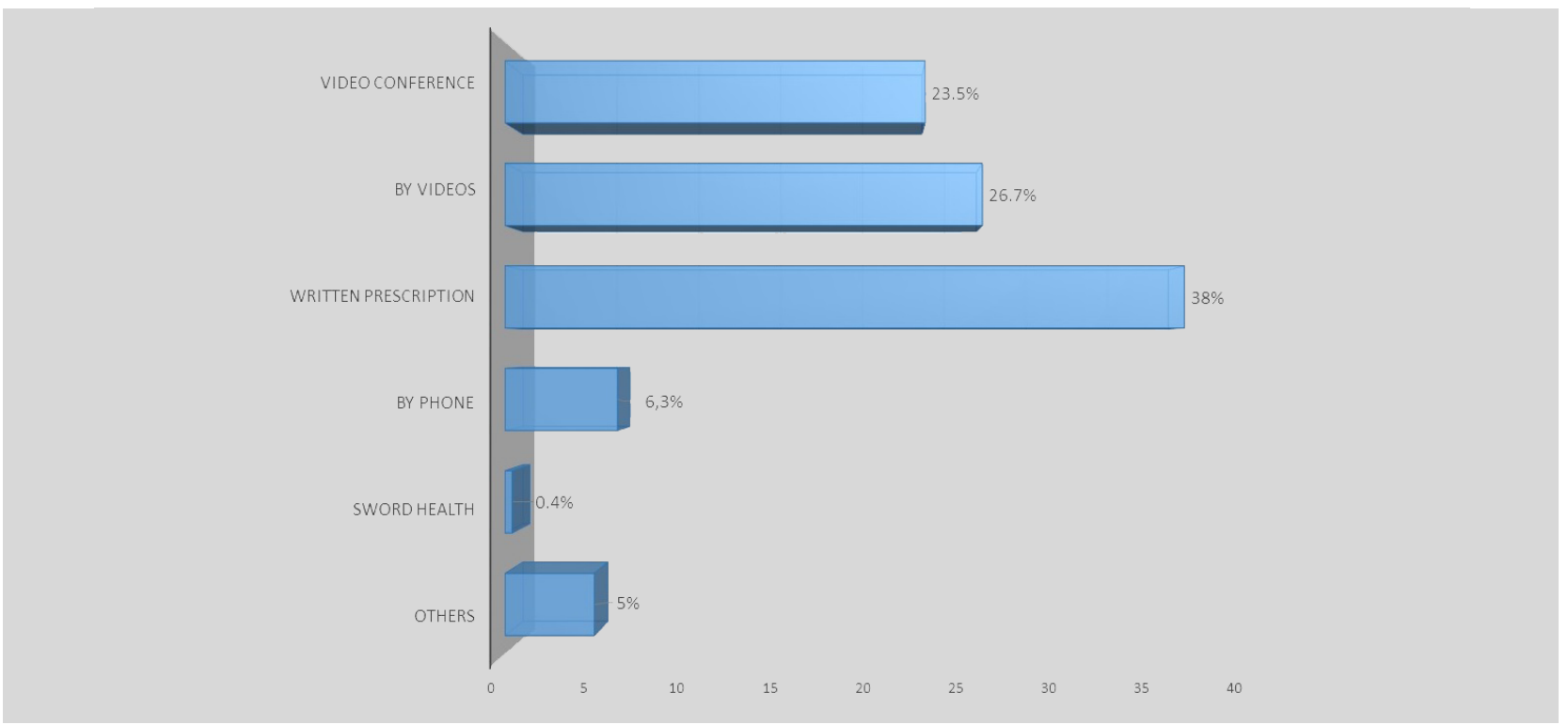

FIGURE 2. WAYS OF MONITORING PATIENTS REMOTELY

with children up to 12 years of age, assistance is equivalent to 1/3 of the average salary. As for employees, the Government created exceptional financial support for those who must stay at home to accompany their children up to 12 years of age, with $66 \%$ of the basic salary being paid to them, 33\% paid by the employer and $33 \%$ paid by the State.

The government took measures to reduce the impact of work interruption for physiotherapists but many patients who need their care are without the main tool of the profession: manual contact. To minimize these problems, most physiotherapists who interrupted their face-to-face practice have followed-up their patients remotely.
The form of monitoring patients most used by physical therapists has been the prescription of treatment in writing. We believe that this measure is related to the difficulty of accessing and using a computer and the internet. Many physiotherapists have also produced videos showing all the exercises to be performed and some use video-conference resources as a way to make live-streamed sessions happen.

A tool not much used and even unknown by many is Sword Health, an application that allows patients to perform physiotherapy sessions at home, monitored in real-time and remotely by a team of physiotherapists and doctors, who prescribe, evaluate, and supervise the entire process. This pandemic forced 
physiotherapists to adapt to the new digital tools in order to keep exercising their profession, just as patients, who also had to adapt to the digital age.

Some adaptations to the physiotherapy session characteristics had to be made since most patients may not have the necessary equipment/materials for its practice at home, space may not be adequate, and there is no faceto-face monitoring by a professional. Probably, changes in the number of sessions per week, as well as changes in the amount charged for it, can be explained by these factors mentioned above. Few physiotherapists maintained the same amount charged per session. However, in some places, such as state health centers, patients do not pay for the sessions, and, in these cases, the values would not be changed.

The objective of this study was not to analyze the ways used by physiotherapists to accompany their patients, in terms of structure, dynamization of sessions, duration, equipment used, among others. In the same way, future studies are suggested to evaluate the effectiveness of conducting sessions at a distance and compare its results with those obtained from face-to-face sessions.

The data in this study also reveals that the physiotherapists who are still working have generally respected the preventive measures applied by the General Directorate of Health of Portugal ${ }^{7}$ and by the World Physiotherapy Confederation, ${ }^{10}$ the most adopted measures being hand washing, the use of protective equipment, and disinfection of materials used.

According to the World Health Organization $(\mathrm{WHO})^{12}$ "physiotherapists assess, plan and implement rehabilitative programs that improve or restore human motor functions, maximize movement ability, relieve pain syndromes, and treat or prevent physical challenges associated with injuries, diseases, and other impairments". Thus, physiotherapy services are necessary not only for chronic patients but also in health promotion and disease prevention and, currently, due to the pathological complications promoted by COVID19 , it is essential to provide physiotherapy services in intensive health care units.

Physiotherapists are professionals who are involved in the monitoring of patients with respiratory conditions in acute, subacute, and chronic contexts, either with spontaneous ventilation or in invasive and non-invasive mechanical ventilation. 13 Given this current pandemic situation, the Portuguese Association of Physiotherapists, together with its Cardiorespiratory Physiotherapy Interest
Group, prepared a position paper with the objective of disseminating the physiotherapist's competences in intensive care, especially in patients infected with COVID -19, and make available, voluntarily, physiotherapists with experience in intensive care to collaborate in this care, 14 since the number of physiotherapists working in this area is still reduced and the number of infected individuals with a high number of morbidities increases every single day.

Some preventive measures to prevent transmission of communicable diseases like COVID-19 include: minimize surface contact, use of a respirator (like N95 respirator) instead of facemask during aerosol-generating procedures (non-invasive ventilation, high flow oxygen therapy, intubation/extubation, nebulization, open suctioning of airway secretions, bronchoscopy, induction of sputum, bag and mask ventilation, cardiopulmonary resuscitation, others), hand hygiene and personal protective equipment, respecting the proper sequence to dress (HH-gown-mask-goggles-gloves) and undress (gloves-goggles-gownmask-HH), disposing of disposable materials when their function is complete, reusable/non-disposable materials must be carefully disinfected according to the manufacturer's recommendations, promote surface cleaning and disinfection frequently. ${ }^{15,16}$ However, $\mathrm{Ng}$ et al. ${ }^{17}$ suggest that the use of surgical masks, hand hygiene, and other standard procedures would be enough to protect health professionals from infection risk, indicating that N95 masks are not superior to surgical masks to prevent influenza infection; though the use of the N95 mask or equivalent equipment while performing an aerosol generation procedure is recommended.

Health professions preventing and controlling Coronavirus Disease 2019 are prone to skin and mucous membrane injury, which may cause acute and chronic dermatitis, secondary infection, and aggravation of underlying skin diseases. This is a consensus of Chinese experts on protective measures and advice on hand- cleaning- and medical-glove-related hand protection, mask- and goggles-related face protection, UV-related protection, eye protection, nasal and oral mucosa protection, outer ear, and hair protection. It is necessary to strictly follow standards of protective equipment and specifications for sterilizing and cleaning. Insufficient and excessive protection will have adverse effects on the skin and mucous membrane barrier. At the same time, using moisturizing products is highly recommended to achieve better protection. 
The use of protective equipment (mask, goggles, gloves) can lead to skin and mucous membrane injury in health professionals. Thus, the use of moisturizing creams is essential to prevent these injuries. Another preventive method can be the use of an adhesive bandage on the skin. ${ }^{15,18}$

All the data for this study were collected between March $26^{\text {th }}$ and April $3^{\text {rd }}$ of 2020. The General Directorate of Health of Portugal published a list of guidelines with measures to all the physiotherapists that work in rehabilitation units and provide respiratory care at home. ${ }^{19}$ Some of those measures are already in place, as it can be observed in the answers given by the professionals that are still delivering their services.

Given that, it becomes necessary to create online courses to promote skill improvement for physiotherapists who work in all areas to prevent the risk of infection. It is believed that a training program, for 1 to 2 weeks, on COVID-19 and public health surveillance could provide essential skills and knowledge, particularly if associated with continuous training and supervision. ${ }^{20}$

It is necessary to emphasize that these professionals can work for long hours under significant pressure, with resources often inadequate, while accepting the dangers inherent to close interaction with sick patients. ${ }^{21}$ Besides that, most health professionals working in isolation units and hospitals do not receive any training for providing mental health care, which includes fear and anxiety. ${ }^{22}$

\section{CONCLUSIONS}

This study showed that most physiotherapists had to interrupt their practice because of COVID-19. However, since they cannot follow up with their patients' treatment in person, most physiotherapists adapted to monitor their patients from a distance using digital tools that are new to their professional activity. This was a necessary strategic measure to prevent the further spread of this pandemic.

\section{Conflict of interest}

None

\section{Contribution of each author}

Elaboration of the measuring instrument, formulation of methodological questions, data collection, data processing: Beatriz Minghelli, Ana Soares, Andreia Guerreiro, Antoine Ribeiro, Carolina Cabrita, Carlos Vitoria, Chloé Nunes, Claudia Martins, Diogo Gomes, Filipa Goulart, Raquel Marreiro dos Santos, Rita Antunes

Elaboration of the article, statistical analysis, literature review, article writing, formulation of methodological questions: Beatriz Minghelli

\section{Acknowledgments}

Gustavo Desouzart for the evaluation of the measurement instrument.

\section{SUMMARY}

INTRODUÇÃo: Os serviços de fisioterapia são necessários para o tratamento de pacientes hospitalizados com COVID-19 e também para pacientes crônicos. Assim, os fisioterapeutas apresentam um maior risco de exposição ao coronavírus. O objetivo deste estudo foi determinar o número de fisioterapeutas que interromperam seus serviços devido à pandemia do COVID-19 e verificar os procedimentos adotados pelos fisioterapeutas que continuam trabalhando.

METODOLOGIA: A amostra foi constituída por 619 fisioterapeutas, que trabalhavam em Portugal, sendo 154 (24,9\%) do sexo masculino e $465(75,1 \%)$ do sexo feminino, com idades compreendidas entre os 22 e 67 anos (34,47 $\pm 8,70$ anos). $O$ instrumento de medida utilizado consistiu num questionário online, tendo sido aplicado em finais de março de 2020, através de contatos e redes sociais.

RESULTADOS: 453 (73.2\%) fisioterapeutas interromperam as suas atividades laborais de forma presencial por causa da pandemia e 166 (26.8\%) continuam a trabalhar presencialmente. As principais medidas adotadas pelos fisioterapeutas que continuam a trabalhar presencialmente incluíram: lavagem das mãos (21.5\%), uso de máscaras (20.3\%), desinfecção do material (19.3\%) e uso de luvas (19.3\%). Dos fisioterapeutas que não estão a trabalhar presencialmente ( $n=453), 267$ (58.9\%) continuam a acompanhar os seus pacientes à distância e 186 (41.1\%) não estão a acompanhar os pacientes. As principais medidas utilizadas pelos fisioterapeutas para acompanhar os seus pacientes à distância incluíram: prescrição do tratamento por escrito (38\%), realização de vídeos explicativos (26.7\%) e tratamento por videoconferência de forma síncrona (23.5\%).

CONCLUSÕES: Os dados do presente estudo revelaram que a maioria dos fisioterapeutas interromperam as suas práticas presenciais em virtude da pandemia COVID-19, no entanto, apesar de não estarem a acompanhar os seus pacientes pessoalmente, a maioria deles elaborou ferramentas para monitorar seus pacientes à distância.

PALAVRAS-CHAVES: COVID-19, fisioterapeutas, medidas adotadas, pandemia, profissionais de saúde 


\section{REFERENCES}

1. Velavan TP, Meyer CG. The COVID-19 epidemic. Trop Med Int Health. 2020 Mar;25(3):278-280

2. Chan JF, Yuan S, Kok KH, To KK, Chu H, Yang J, Xing F, Liu J, Yip CCY, Poon RWS, Tsoi HW, Lo SK, Chan KH, Poon VK, Chan WM, Ip JD, Cai JP, Cheng VC, Chen H, Hui CK, Yuen KY. A familial cluster of pneumonia associated with the 2019 novel coronavirus indicating person-to-person transmission: A study of a family cluster. Lancet. 2020;395:514-523

3. World Health Organization [internet]. Coronavirus disease (COVID-19) Pandemic. [accessed on April 6, 2020]. Available at: https://www.who.int/ emergencies/diseases/novel-coronavirus-2019

4. World Health Organization [internet]. Coronavirus disease (covid-19) outbreak: rights, roles and responsibilities of health workers, including key considerations for occupational safety and health. [accessed on Mar 31, 2020]. Available at: https://www.who.int/docs/default-source/coronaviruse/who-rights-roles-respon-hw-covid-19.pdf?sfvrsn=bcabd401_0

5. Deng SQ, Peng HI. Characteristics of and Public Health Responses to the Coronavirus Disease 2019 Outbreak in China. J Clin Med. 2020 Feb 20;9(2). pii: E575. doi: 10.3390/jcm9020575

6. World Health Organization [internet]. Coronavirus disease (COVID-19) advice for the public. [accessed on Mar 31,2020]. Available at: https://www. who.int/emergencies/diseases/novel-coronavirus-2019/advice-for-public; .

7. Direção-Geral da Saúde. Portugal. Orientação n 013/2020 de 21/03/2020

8. World Confederation for Physical Therapy [internet]. Coronavirus disease (COVID-19) advice for the public. [accessed on Mar 31, 2020]. Available at: https://www.wcpt.org/policy/ps-descriptionPT

9. Thomas P, Baldwin C, Bissett B, Boden I, Gosselink R, Granger CL, Hodgson CL, Jones AYM, Kho ME, Moses R, Ntoumenopoulos G, Parry SM, Patman $S$, van der Lee L (2020): Physiotherapy management for COVID-19 in the acute hospital setting. Recommendations to guide clinical practice. Version 1.0, published 23 March 2020. Journal of Physiotherapy

10. Schaeffer R, Mendenhall W, Ott L, Gerow K. Elementary Survey Sampling. (7th ed). Boston: Brooks/Coles; 2011

11. World Health Organization [internet]. Classifying health workers: Mapping occupations to the international standard classification. [accessed on Mar 30, 2020]. Available at: https://www.who.int/hrh/statistics/Health_workers_classification.pdf).

12. Gosselink R, Bott J, Johnson M, Dean E, Nava S, Norrenberg M, et al. Physiotherapy for adult patients with critical illness: recommendations of the European Respiratory Society and European Society of Intensive Care
Medicine Task Force on physiotherapy for critically ill patients. Intensive care medicine 2008;34(7):1188-99

13. Associação Portuguesa de Fisioterapeutas [internet]. Tomada de Posição da Associação Portuguesa de Fisioterapeutas - O papel do fisioterapeuta em cuidados intensivos e da disponibilidade de reforço de resposta na sequência da pandemia COVID-19. APFISIO. 26/03/2020. [accessed on Mar 30, 2020]. Available at: http://www.apfisio.pt/wp-content/uploads/2020/03/ APFISIO_Posicao-COVID-19_26Mar20.pdf

14. Huh $\mathrm{S}$. How to train the health personnel for protecting themselves from novel coronavirus (COVID-19) infection during their patient or suspected case care. J Educ Eval Health Prof 2020;17:10. doi: 10.3352/jeehp.2020.17.10

15. Malhotra N, Gupta N, Ish S, Ish P. COVID-19 in intensive care. Some necessary steps for health care workers. Monaldi Arch Chest Dis 2020;90(1) doi: 10.4081/monaldi.2020.1284

16. Ng K, Poon B, Kiat Puar T, Shan Quah J, Loh W, Wong Y, Tan T, Raghuram J. COVID-19 and the Risk to Health Care Workers: A Case Report. Ann Intern Med 2020. doi: 10.7326/L20-0175

17. Yan $Y$, Chen $H$, Chen $L$, Cheng $B$, Diao P, Dong $L$, Gao X, Gu H, He L, Ji C, Jin H, Lai W, Lei T, Li L, Li L, Li R, Liu D, Liu W, Lu Q, Shi Y, Song J, Tao J, Wang B, Wang G, Wu Y, Xiang L, Xie J, Xu J, Yao Z, Zhang F, Zhang J, Zhong $\mathrm{S}$, $\mathrm{Li} \mathrm{H}, \mathrm{Li} \mathrm{H}$. Consensus of Chinese experts on protection of skin and mucous membrane barrier for health-care workers fighting against coronavirus disease 2019. Dermatol Ther 2020:e13310. doi: 10.1111/dth.13310

18. Direção-Geral da Saúde. Portugal. Orientação n 020/2020 de 03/04/2020 - COVID-19: fase de mitigação. Cuidados de Reabilitação e Respiratórios Domiciliários. Available at: https://www.dgs.pt/directrizes-da-dgs/ orientacoes-e-circulares-informativas/orientacao-n-0202020-de03042020-pdf.aspx?fbclid=IwAR2-_Xkh/dQrwoMXUIP-QlekxMcF96zHtIMq5rPoEnQNzBvZNdMKnP1DLrE

19. Haines A, de Barros EF, Berlin A, Heymann DL, Harris MJ. National UK programme of community health workers for COVID-19 response. Lancet 2020. pii: S0140-6736(20)30735-2. doi: 10.1016/ S0140-6736(20)30735-2

20. Schwartz |, King CC, Yen MY. Protecting Health Care Workers during the COVID-19 Coronavirus Outbreak -Lessons from Taiwan's SARS response. Clin Infect Dis 2020. pii: ciaa255. doi: 10.1093/cid/ciaa255

21. Lima CKT, Carvalho PMM, Lima IAAS, Nunes JVAO, Saraiva JS, de Souza RI, da Silva CGL, Neto MLR. The emotional impact of Coronavirus 2019-nCoV (new Coronavirus disease). Psychiatry Res 2020;287:112915. doi: 10.1016/j. psychres.2020.112915 